\title{
HUBUNGAN PENGETAHUAN DAN SIKAP IBU NIFAS TENTANG PERAWATAN LUKA PERINEUM DENGAN PENYEMBUHAN LUKA PERINEUM DI WILAYAH KERJA UPT. PUSKESMAS GAJAH MADA DAN WILAYAH KERJA UPT. PUSKESMAS TEMBILAHAN HULU
}

\author{
Nurul Indah Sari ${ }^{1}$, Lisa². \\ ${ }_{1,2}$ Dosen Akademi Kebidanan Husada Gemilang, Mahasiswa Akademi Kebidanan Husada Gemilang
}

Email: nurulindahsari4188@gmail.com (korespondensi)

\begin{abstract}
Perineum wound is the area which is diffcult to maintain to keep it dry and clean. Special observation and treatment is needed to ensure the area can heal by doing proper perineum care and it will cause infections complications due to errors in perineum wound care. From initial survey that was done by doing interview method in Public Healt Center of Gajah Mada and Tembilahan Hulu with 6 patients (100\%) only knew how to treat perineum wound by changing sanitary pads at least twice a day whitout washing hands before and after doing treatment perineum wound. This research design is anlytic observational by using cross sectional approach. The popolation in this research is puerperium mother is 2019 in UPT of public Healt Center Gajah Mada and Tembilahan Hulu with total per month is 134 persons. Taking sampel by using accidental sampling by the amount 32 persons. Data collecting tool is using cheklist sheet of observation sheet. The test result chi square in knowledge and attiude of perineum mother toward perineum wound treatment and perineum wound healing was obtain 0,000 it means there is relationship between knowledge and attiude of perineum mother toward perineum wound treatmen and perineum wound healing. It is expected to increase perineum mother's knowladge by doing promotive effort like counseling at first visiting on puerperium period by using media that can be brought to go home by patients like brochurenor leaflet so that patiens can read again after they are at home.
\end{abstract}

Keywords: Perineum wound treatment

\begin{abstract}
Abstrak
Luka pada perineum merupakan daerah yang sulit dijaga agar tetap kering dan bersih. Pengamatan dan perawatan khusus diperlukan untuk menjamin daerah tersebut agar dapat sembu dengan melakukan perawatan perineum yang benar dan akan menimbulkan komplikasi infeksi akibat kesalahan dalam melakukan perawatan luka perineum. Dari survey awal yang di lakukan dengan metode wawancara di Puskesmas Gajah Mada dan Tembilahan Hulu sebanyak 6 orang (100\%) pasien hanya mengetahui merawat luka perineum dengan mengganti pembalut minimal 2 kali sehari tanpa mencuci tangan sebelum dan sesudah melakukan perawatan luka perineum. Desain penelitian ini adalah observasional analitik dengan menggunakan pendekatan cross sectional. Populasi pada penelitian ini adalah sasaran ibu nifas pada tahun 2019 di UPT. Puskesmas Gajah Mada dan Tembilahan Hulu yaitu dengan total perbulan 134 orang. Pengambilan sampel dengan menggunakan accidental sampling, dengan jumlah sebanyak 32 orang. Alat pengumpulan data dengan menggunakan lembar checklist dan lembar observasi. Hasil uji chi square pada pengetahuan dan sikap dan sikap ibu nifas tentang perawatan luka perineum dengan penyembuhan luka perineum di peroleh nilai 0,000 yang artinya ada hubugan pengetahuan dan sikap ibu nifas tentang perawatan luka perineum dengan penyembuhan luka perineum. Diharapkan dapat meningkatkan pengetahuan ibu nifas dengan melakukan upaya promotif seperti penyuluhan pada kunjungan pertama masa nifas dengan menggunakan media yang bisa dibawa pulang oleh pasien seperti brosur atau leaflet, sehingga pasien bisa membaca kembali setelah dirumah.
\end{abstract}

Kata kunci: Pengetahuan, Sikap, Penyembuhan Luka Perineum 


\section{Pendahuluan}

Masa nifas (puerperium) dimulai setelah plasenta lahir dan berakhir ketika alat-alat kandungan kembali seperti keadaan sebelum hamil. Masa nifas berlangsung selama kirakira 6 minggu atau 42 hari (Yulianti,2018).Asuhan selama periode nifas perlu mendapat perhatian karena sekitar $60 \%$ angka kematian ibu terjadi pada periode ini (Martalina, 2012)

Berdasarkan data dari World Health Organization (WHO) diseluruh dunia sekitar830 wanita meninggal setiap hari karenakomplikasi selama kehamilan atau persalinanpada tahun 2015, sedangkan di Indonesia tahun 2015 Angka Kematian Ibu (AKI) tergolong masih tinggi dibanding dengan Negara-Negara ASEAN yaitu sebesar 305 per 100.000 kelahiran hidup(Dinas Kesehatan Provinsi Riau).Begitu juga di Provinsi Riau tingkat kematian ibu saat melahirkan pada tahun 2015adalah 108,9/100.000 kelahiran hidup (Dinas Kesehatan Provinsi, Riau) penyebab kematian tersebut yaitu perdarahan, hipertensi dalam kehamilan dan infeksi masa nifas. Sementara jumlah AKI pada tahun 2018di Indragiri Hilir adalah 9 orang, adapun penyebab kematian ibu $50 \%$ diantaranya akibat penyakit yang memperburuk semasa kehamilannya sampai dia melahirkan sedangkan $50 \%$ nya adalah akibat perdarahan sewaktu melahirkan serta faktor resiko tinggi, pre eklamsi dan infeksi masa nifas (Dinas Kesehatan Kabupaten Indragiri Hilir, 2018). Infeksi nifas dapat disebabkan seperti bakteri endogen dan bakteri eksogen, faktor predis posisi seperti nutrisi yang buruk, rupture membrane, dan luka episiotomi (Yulianti, 2018).

Luka pada perineum atau episiotomi merupakan daerah yang sulit dijaga agar tetap bersih dan kering. Pengamatan dan perawatan khusus diperlukan untuk menjamin daerah tersebut agar dapat sembuh dengan cepat dengan melakukan perawatan pada luka perineum secara benar dalam (Moloku,2013). Sikap ibu dalam melakukan perawatan luka perineum dipengaruhi oleh pengetahuan yang dimiliki oleh ibu yang didapat dari orang tuanya (tradisi), tenaga kesehatan dan media cetak, dengan demikian sikap ibu dalam melakukan perawatan luka perineum sangat menentukan kesehatan ibu (Barbara, dalam Sari, 2012)

Oleh karena itu pemerintah mengupayakan melalui kunjungan nifas diharapkan dengan adanya kunjungan nifas terdeteksi masalah kesehatan selama masa nifas, serta memberikan penjelasan tentang kesehatan secara umum dan perawatan luka perineum. Pengetahuan ibu nifas tentang perawatan luka perineum yang kurang baik akan mempengaruhi penyembuhan luka perineum. Pengetahuan rendah atau kurang kemungkinan terjadi infeksi akan lebih besar karena kesalahan dalam perwawatan luka perineum (Manuaba, 2009).

Dari hasil penelitian yang dilakukan oleh (Srianti, 2017), hasil wawancara langsung yang dilakukan peneliti pada 7 orang ibu post partum normal yang ada pada saat pengambilan data awal, ditemukan 3 orang ibu mengatakan membersihkan perineumnya hanya dengan air tanpa sabun, 2 orang ibu mengatakanjarang mengganti pembalut sehingga mereka merasa kurang nyaman serta bau vagina yang tidak enak, sedangkan 2 orang ibu lainnya mengatakan tidak mencuci tangan sebelum membersihkan luka jahitan perineum sehingga seringkali menimbulkan gatal-gatal, kemudian setelah diwawancarai juga mengenai keadaan luka perineum pada hari ketiga, mereka mengatakan bahwa masih ada sisa-sisa cairan yang keluar dari alat genetalia.Begitu pula dengan hasil penelitian yang dilakukan oleh (Nurrahmaton, 2018) didapatkan hasil yaitu ada hubungan antara pengetahuan ibu nifas tentang perawatan luka perenium dengan proses penyembuhan luka perenium

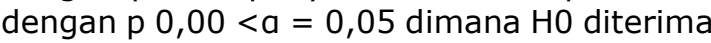
dan $\mathrm{Ha}$ ditolak.

Berdasarkan survey pendahuluan yang dilakukan pada tanggal 30 April 2019 di Wilayah Kerja UPT. Puskesmas Gajah Mada dengan melakukan wawancara kepada 4 orang ibu nifas sedang dirawat inap diruang persalinan, 4 orang ibu nifas tersebut tidak mengetahui dengan tentang perawatan luka perineum dengan baik, karena hanya mengganti pembalut $1 / 2$ kali sehari, tanpa mencuci tangan sesudah dan sebelum melakukan perawatan, tanpa menyiram perineum dengan air hangat, mengeringkan dengan tisu atau handuk kecil.

Begitu juga hasil survey yang dilakukan pada tanggal 12 Juli di wilayah kerja Puskesmas Tembilahan Hulu dengan melakukan wawancara kepada 2 orang ibu nifas yang sedang dirawat inap diruang perawatan yang kurang mengetahui cara perawatan luka perineum dengan benar. Pada saat praktik klinik di Puskesmas Gajah Mada dan Tembilahan Hulu masih banyak ibu yang kurang tahu tentang perawatan perineum dengan baik.

Penelitian ini bertujuan untuk mengetahui Hubungan Pengetahuan Ibu Nifas Tentang Perawatan Luka Perineum dengan 
Penyembuhan Luka Perineum di Wilayah Kerja UPT. Puskesmas Gajah Mada Tahun 2019

\section{TINJAUAN PUSTAKA}

\subsection{Pengetahuan}

\subsubsection{Definisi}

Pengetahuan adalah hasil dari tahu/ mengetahui dan terjadi setelah orang melakukan pengindraan terhadap suatu objek tertentu. Pengindraan terjadi melalui pancaindra pengelihatan, pendengaran, penciuman, perasa, dan peraba. Sebagian besar pengetahuan masyarakat atau manusia diperoleh melalui mata dan telinga. Pengetahuan merupakan pedoman dalam bentuk tindakan seseorang (overt behavior). Berdasarkan pengalaman dan penelitian bahwa prilaku yang didasari oleh pengetahuan akan lebih bertahan lama dari pada prilaku yanag tidak didasari oleh pengetahuan (Maryam, 2017).

\subsubsection{Faktor yang pengetahuan}

a. Faktor Internal

1) Pendidikan

Pendidikan berarti bimbingan yang diberikan seeorang terhadap perkembangan orang lain menuju ke arah cita-cita tertentu yang menentukan manusia untuk berbuat dan mengisi kehidupan untuk mencapai keselamatan dan kebahagiaan. Pendidikan diperlukan untuk mendapatkan informasi misalnya hal-hal yang menunjang kesehatan sehingga dapat meningkatkan kualitas hidup pendidikan dapat mempengaruhi seseorang termasuk juga perilaku seseorang akan pola hidup.

2) Pekerjaan

Pekerjaan adalah keburukan yang harus dilakukan terutama untuk menunjang kehidupannya dan kehidupan keluarga. Pekerjaan bukanlah sumber kesenangan, tetapi lebih banyak merupakan cara mencari nafkah yang membosankan, berulang dan banyak tantangan. Sedangkan bekerja umumnya merupakan kegiatan yang menyita waktu.

3) Umur

Umur adalah individu yang terhitung mulai saat dilahirkan sampai berulang tahun. Semakin cukup umur, tingkat kematangan dan kekuatan seseorang lebih matang dalam berfikir dan bekerja. Dari segi kepercayaan masyarakat seseorang yang lebih dewasa dipercaya dari orang yang belum tinggi kedewasaannya.

b. Faktor Eksternal

1) Faktor Lingkungan

Merupakan seluruh kondisi yang ada disekitar manusia dan pengaruhnya yang dapat mempengaruhi perkembangan dan perilaku orang atau kelompok.

2) Sosial Budaya

Sistem sosial budaya yang ada pada masyarakat dapat mempengaruhi dan sikap dalam menerima informasi, di lingkungan maupun di masyarakat (Wawan, 2010).

\subsubsection{Kriteria pengetahuan}

Pengukur pengetahuan dapat dilakukan dengan wawancara atau angket yang menanyakan tentang isi materi yang ingin diukur dari subjek penelitian atau responden. Kedalaman pengetahuan yang ingin kita ketahui atau kita ukur sesuaikan dengan tingkat-tingkat diatas (Notoadmojo, 2010). Cara mengukur tingkat pengetahuan dengan memberi pertanyaan-pertanyaan, kemudian dilakukan penelitian 1 untuk menjawab benar atau 0 untuk jawaban salah. Menurut (Hidayat, 2014), berdasaarkan prestase cara interpritas yaitu :
a. Baik angkanya
$: \geq 50 \%$

b. Kurang baik angkanya : $<50 \%$

\subsection{Sikap \\ 2.2.1. Definisi}

Sikap adalah perasaan pikiran, dan kecendrungan seseorang yang kurang lebih bersifat permanen mengenai aspek-aspek tertentu dalam lingkungannya. Sikap merupakan kecondongan evaluatif terhadap suatu stimulasi atau objek yang berdampak pada bagaimana seseorang berhadapan dengan objek tersebut. Ini berarti sikap dapat menunjukan kesetujuan atau ketidaksetujuan, suka atau tidak suka seseorang terhadap sesuat. Sikap juga dikaitkan dengan pendidikan yaitu sikap atau tanggapan peserta didik terhadap materi pendidikan yang diberikan (Mubarak, 2011).

Seorang ahli psikologis sosial (Newcomb) menyatakan bahwa sikap adalah kesiapan atau kesediaan untuk bertindak dan bukan merupakan pelaksanaan motif tertentu. Sikap belum merupakan suatu tindakan atau aktivitas, akan tetapi merupakan predisposisi 
tindakan prilaku.

\subsubsection{Faktor yang mempengaruhi sikap}

Azwar (2013) menuliskan bahwa sikap seseorang dipengaruhi oleh beberapa hal berikut :

a. Lingkungan

1) Rumah

Tingkah laku anak dan sikap anak tidak hanya dipengaruhi oleh bagaimana sikap-sikap orang yang berada di dalam rumah itu, melainkan juga bagaimana sikapsikap mereka dan bagaimana mereka mengadakan atau melakukan hubungan-hubungan dengan orangorang di luar rumah. Dalam hal ini, peranan orang tua penting sekali untuk mengetahui apa-apa yang dibutuhkan si anak dalam rangka perkembangan nilai-nilai moral si anak, serta bagaimana orang tua dapat memenuhinya. Dalam hal ini, orang tua dan orang sekitar berperan dalam membentuk pengetahuan anak yang akan membentuk sikap anaktersebut

\section{2) Sekolah}

Peran pranata pendidikan adalah untuk membentuk kepribadian anggota masyarakat agar menjadi warga yang baik dan unggul secara intelektual. Peran guru sejak pendidikan dasar sangat besar mempengaruhi pola pikir, perilaku, sikap anak dalam membentuk kepribadiannya. Guru senantiasa memberikan dorongan dan motivasi terhadap keberhasilan anak dalam membentuk kepribadian anak. Ketika anak memasuki sekolah lanjutan, peran guru dalam mempengaruhi kepribadian anak mulai dibatasi oleh peran anak itu sendiri. Pada tahap ini, anak sudah mempunyai sikap, kepribadian, dan kemandirian (Wigati,2008)

3) Pekerjaan

Lingkungan pekerjaan sangatlah seseorang, kondisi lingkungan pekerjaan yang nyaman, akan membentuk sikap positif pada pekerjanya, begitu sebaliknya lingkungan kerja yang tidak nyaman akan membentuk sikap negatif pada pekerjanya (Heni, 2011). Dari gambaran tersebut, dapat disimpulkan bahwa lingkungan pekerjaan sangat berperan dalam mekanisme pembentukan sikap. Kenyamanan pada lingkungan kerja, akan membawa sikap positif pada kehidupan orang tersebut.

4) Pengalaman

Apa yang telah dan sedang dialami seseorang, akan ikutmembentuk dan mempengaruhi penghayatan seseorang terhadap stimulus sosial. Tanggapan akan menjadi salah satu dasar terbentuknya sikap (Azwar, 2013). Pengalaman dapat didapatkan dari pendidikan dari suatu instansi,pernahmengalami suatu kejadian, dan pernah melihat dari orang lain. Pengalaman sangat mempengaruhi seseorang dalam bersikap.

5) Umur

Umur merupakan salah satu fakor yang mempengaruhi sikap seseorang. Menurut Suryabudi (2003), seseorang yang menjalani hidup secara normal dapat diasumsikan bahwa semakin lama hidup maka pengalaman semakin banyak, pengetahuan semakin luas, keahlian semakin mendalam dan kearifannya semakin baik dalam mengambil keputusan tindakannya.

6) Pendidikan

Pendidikan bisa berupa pendidikan formal, yaitu dari sekolah, maupun pendidikan nonformal, seperti pendidikan dari orang tua sehingga terbentuknya sikap seseorang (Sugiarto, 2004). Rusmi (2009) mengatakan bahwa pembentukan sikap dan faktor-faktor yang berpengaruh terhadap pembentukan sikap seseorang sangat ditentukan oleh kepribadian, intelegensia,dan minat.

\subsubsection{Cara mengukur sikap}

Pengukuran sikap dilakukan secara langsung dan tidak langsung dapat ditanyakan bagaimana pendapat dan bagaimana pendapat dan pernyataan responden terhadap suatu obyek. Secara tidak langsung dapaat dilakukan dengan pertanyaan-pertanyaan hipotesis kemudian dinyatakan pendapat respon melalui kuesioner (Notoatmojo, 2010).

Menurut (Hidayat, 2010), pernyataan/pernyataan sikap menggunakan skala likert dengan beberapa bentuk jawaban, pertanyaan/pernyataan positif dan negatif. 
Tabel 1. Pengukuran Skala Likert

\begin{tabular}{cccc}
\hline No & Kriteria & $\begin{array}{c}\text { Nilai } \\
\text { Positif }\end{array}$ & $\begin{array}{c}\text { Nilai } \\
\text { Negatif }\end{array}$ \\
\hline 1 & Sangat Setuju & 4 & 1 \\
\hline 2 & Setuju & 3 & 2 \\
\hline 3 & Tidak Setuju & 2 & 3 \\
\hline 4 & Sangat Tidak Setuju & 1 & 4 \\
\hline
\end{tabular}

Cara penilaian sikap adalah dengan cara memberikan pernyataan positif dan negatif, dengan nilai menurut skala liker. Menurut (Hidayat, 2014), berdasarkan presentase cara interpretasi yaitu:

1. Baik angkanya $=\geq$ mean

0 . Kurang baik angkanya $=<$ mean

\subsection{Perawatan luka perineum}

\subsubsection{Definisi}

Perineum adalah jaringan yang terletak disebelah distal diafragma pelvis. Perineum mengandung sejumlah otot superfisial, saat persalinan, otot ini sering mengalami kerusakan ketika janin dilahirkan (Rohani dalam Fitriani,2017)

Perawatan perineum adalah pemenuhan kebutuhan untuk menyehatkan daerah antara paha yang dibatasi vulva dan anus pada ibu yang dalam masa antara kelahiran plasenta sampai dengan kembalinya organ genetik seperti pada waktu sebelum hamil (Rukiyah,2010).

\subsubsection{Luka Perineum}

Luka perineum setelahkan melahirkan dibagai menjadi dua :

a. Ruptur adalah luka pada perineum yang diakibatkan oleh rusaknya jaringan secara alamiah karena proses desakan kepala janin atau bahu pada saat proses persalinan. Bentuk ruptur biasanya tidak teratur sehingga jaringan yang robek sulit dilakukan penjahitan (Rukiyah, 2010).

b. Episiotomi adalah incisi dari perineum untuk memudahkan persalinan dan mencegah rupture perineum totalis. Episiotomi dilakukan ketika kepala sudah tampak 2-3 cm di vulva. (Rukiyah,2010)

\subsubsection{Tujuan Perawatan Luka Perineum}

Tujuan perawatan perineum adalah mencegah terjadinya infeksi sehubungan dengan penyembuhan jaringan (Rukiyah,2010).

\subsubsection{Cara Perawatan Luka Perineum}

Menurut (Yulianti,2018) cara melakukan perawatan perenium adalah :

a. Persiapan ibu post partum

Perawatan perineum sebaiknya dilakukan di kamar mandi dengan posisi ibu jongkok jika ibu telah mampu atau berdiri dengan posisi kaki terbuka

b. Penatalaksanaan perawatan perineum

Khususnya parineal bagi wanita setelah melahirkan anak mengurangi rasa ketidaknyamanan, kebersihan, mencegah infeksi, dan meningkatkan penyembuhan dengan prosedur pelaksanaan adalah sebagai berikut (Mardiah,2013) :

1) Mencuci tangan.

2) Buang pembalut yang telah penuh dengan gerakan kebawah mengarah kerectum dan letakkan pembalut tersebut kedalam kantong pelastik.

3) Berkemih dan buang air besar ke toilet.

4) Membersinkan vulva dari depan kebelakang sampai daerah sekitar anus

5) Mengganti pembalut minimal 2 kali sehari

6) Keringkan perineum dengan menggunakan tissue handuk kecil

7) Pasang pembalut dari depan kebelakang

8) Cuci tangan kembali

c. Evaluasi

Parameter yang digunakan dalam evalusi hasil perawatan adalah :

1) Perineum tidak lembab

2) Posisi pambalut tepat

3) Ibu merasa nyaman.

\subsubsection{Faktor yang mempengaruhi} penyembuhan luka perineum

a. Umur

Faktor umur salah saatu faktor yang dapat mempengarhi penyembuhan luka. Penyembuhan luka lebih cepat terjadi pada umur muda dari pada orang tua. Sebab fungsi penyatuan organ jaringan pada kulit ibu post partum yang sudah tidak usia reproduktif telah mengalami penurunan akibat faktor usia yaitu < 20 tahun dan > 35 tahun dan umur yang reproduktif adalah 20-35 tahun Dalam (Rohmin, 2017)

Semakin tua seseorang maka akan menurunkan kemampuan untuk penyatuan jaringan pada saat orang 
tersebut mengalami luka, dan semakin tua seseorang maka semakin lama penyembuhan luka yang berlangsung. Hal ini sesuai dengan teori yang dikemukakan oleh (Diaryasa, 2010) bahwa penambahan usia berpengaruh terhadap penyembuhan luka perineum sehubungan dengan adanya gangguan sirkulasi dan koagulasi. Kulit pada orang dewasa muda yang sehat merupakan suatu barier yang baik terhadap trauma mekanis dan infeksi, yang memungkinkan penyembuhan luka terjadi lebih cepat.

b. Pendidikan

Adapun macam-macam tingkat pendidikan antara lain dalam Herawati (2010) :

1) Tidak sekolah

2) Pendidikan dasaar (SD-SMP/MTS)

3) Pendidikan menengah (SMA/SMK)

4) Pendidikan tinggi (D3/S1)

Pendidikan pada dasarnya berpengaruh terhadap perawatan luka perineum yang dilakukan ibu, ibu nifas dengan tingkat pendidikan yang baik akan memiliki pengetahuan yang lebih besar dibandingkan ibu ifas yang berpendidikan rendah.

Pendidikan yang tinggi akan mudah menerima informasi dan semakin banyak pula pengetahuan yanag dimiliki sehingga ibu yang memiliki pengatahuan baik akan mudah menerima informasi mengenai asuhan yang diberikan oleh bidan mengenai perawatan pasca melahirkan. Sebaliknya pendidikan yang rendah akan menghambat perkembangan sikap seseorang terhadap nilai-nilai yang abru diperkenalkan. Dengan jenjang yang masih kurang pada pendidikan dasar menyebabkan informasi dan pengetahuan kurang, termasuk pengetahuan tentang perawatan pasca persalinan (Smelzer, 2010).

c. Pekerjaan

Menurut Hendra Poerwanto (2013) kategori pekerjaan dibagi manjadi 6 yaitu :

1) PNS

2) IRT

3) Honorer/kontrak

4) Swasta

5) Buruh

6) Wiraswasta

Pekerjaan dalam hal ini juga dapat mempengaruhi ibu nifas dalam melakukan perawatan perineum, dimana ibu yang bekerja akan mudah mendapatkan informasi yang dibutuhkan seperti perawatan perineum dibandingkan ibu yang tidak bekerja. Selain itu pekerjaan juga mempengaruhi sosial ekonomi untuk menyediakan sarana prasarana dalam melakukan perawatan perineum (Smelzer,2010).

Ibu post partum yang bekrja dirumah terdapat keterbatasan untuk memperoleh informasi kecuali jika ibu dengan ekonomi menengah ke atas bisa memperoleh informasi melalui handphone, terkadang mereka belum mendapat informasi yang benar tentang perawatan luka perineum secara benar. Ibu rumah tangga memiliki kegiatan yang hanya terbatas dalam rumah saja, dan kemungkinan untuk bertukar pikiran dan pengalaman dengan orang-orang diluar sangat terbatas, dalam hal cara melakukan perawatan luka perineum secara benar. Dalam (Sari, 2019).

\section{METODOLOGI PENELITIAN}

Penelitian ini bersifat analitik dengan desain cross sectional. Populasi dalam penelitian ini adalah seluruh Ibu Nifas normal dengan luka perineum pada tahun 2019 di Wilayah Kerja UPT. Puskesmas Gajah Mada sebanyak 647 orang dan di Wilayah Tembilahan Hulu sebanyak 966 orang dengan jumlah total sasaran sebanyak 1.613 orang dan dibagi 12 bulan dengan jumlah 134 orang (KIA Puskesmas UPT. Puskesmas Gajah Mada dan Tembilahan Hulu). Sampel pada penelitian ini adalah 32 orang dan teknik pengambilan sampel dalam penelitian ini adalah dengan menggunakan accidental sampling. Pengolahan data dilakukan dengan tahap editing, coding, processing, cleaning dan tabulating. Analisis data yang dilakukan yaitu analisis univariat dan analisis bivariat uji Chi Square.

\section{HASIL DAN PEMBAHASAN}

\subsection{Analisis Univariat}

Resume hasil analisis univariat dapat dilihat pada tabel berikut :

a. Data Umum

Tabel 2. Distribusi Frekuensi Karakteristik Responden 


\begin{tabular}{lcc}
\hline Karakteristik & Frekuensi & presentase \\
\hline Umur & & \\
Tidak reproduktif (<20-> & 1 & 31,1 \\
30 thn) & 31 & $96,6 \%$ \\
Reproduktif (20-30 thn) & $\mathbf{3 2}$ & $\mathbf{1 0 0 \%}$ \\
\hline Total & & \\
\hline Pendidikan & 11 & $34,4 \%$ \\
Pendidikan dasar & 17 & $53,1 \%$ \\
Pendidikan menengah & 4 & $12,5 \%$ \\
Perguruan tinggi & $\mathbf{3 2}$ & $\mathbf{1 0 0 \%}$ \\
\hline Total & & \\
\hline Pekerjaan & 23 & $71,9 \%$ \\
IRT & 4 & $12,5 \%$ \\
Honorer/kontrak & 1 & $3,1 \%$ \\
Swasta & 4 & $12,5 \%$ \\
Wiraswasta & $\mathbf{3 2}$ & $\mathbf{1 0 0 \%}$ \\
Total & & \\
\hline
\end{tabular}

Dari tabel 1 dapat dilihat bahwa sebagian besar responden berumur reproduktif (20-35 tahun) sebanyak 31 orang $(96,6 \%)$, responden berpendidikan menengah sebanyak 17 orang $(53,1 \%)$ dan sebagian besar responden bekerja sebagai IRT sebanyak 23 orang (71,9\%).

b. Data Khusus

Tabel 3. Distribusi Frekuensi Pengetahuan Ibu Nifas Tentang Perawatan Luka Perineum

\begin{tabular}{lcc}
\hline Pengetahuan & Jumlah & Presentase \\
\hline Baik & 23 & $71,9 \%$ \\
Kurang baik & 9 & $28,1 \%$ \\
\hline Total & $\mathbf{3 2}$ & $\mathbf{1 0 0 \%}$ \\
\hline
\end{tabular}

Berdasarkan tabel 2 dapat dilihat bahwa responden yang berpengetahuan baik sebanyak 23 orang $(71,9 \%)$ dan berpengetahuan kurang baik sebanyak 9 orang $(28,1 \%)$.

Tabel 4. Distribusi Frekuensi Sikap Ibu Nifas Tentang Perawatan Luka Perineum

\begin{tabular}{lcc}
\hline Sikap & Jumlah & Presenatse \\
\hline Baik & 24 & $75,0 \%$ \\
Kurang Baik & 8 & $25 \%$ \\
\hline Total & $\mathbf{3 2}$ & $\mathbf{1 0 0 \%}$ \\
\hline
\end{tabular}

Berdasarkan tabel 3 dapat dilihat bahwa responden yang sikapnya baik sebanyak 24 orang $(75,0 \%)$ dan sikap kurang baik sebanyak 8 orang $(25,0 \%)$.

Tabel 5. Distribusi Frekuenasi Penyembuhan Luka Perineum Pada Ibu Nifas

\begin{tabular}{lcc}
\hline $\begin{array}{l}\text { Penyembuhan Luka } \\
\text { Perineum }\end{array}$ & Jumlah & Presenatse \\
\hline Baik & 23 & $71,9 \%$ \\
Buruk & 9 & $28,1 \%$ \\
\hline Total & $\mathbf{3 2}$ & $\mathbf{1 0 0 \%}$ \\
\hline
\end{tabular}

Berdasarkan tabel 4 dapat dilihat bahwa responden yang luka perineumnya baik sebanyak 23 orang ( 71,9\%) dan penyembuhan luka perineum buruk sebanyak 9 orang $(28,1 \%)$.

\subsection{Analisis Bivariat}

Tabel 6 Hubungan Pengetahuan Ibu Nifas Tentang Perawatan Luka Perineum dengan Penyembuhan Luka Perineum

\begin{tabular}{|c|c|c|c|c|c|c|c|c|}
\hline \multirow[t]{3}{*}{$\begin{array}{l}\text { Pengetahu } \\
\text { an }\end{array}$} & \multicolumn{4}{|c|}{$\begin{array}{l}\text { Penyembuhan } \\
\text { luka perineum }\end{array}$} & \multirow[t]{2}{*}{$\begin{array}{c}\text { Tota } \\
1\end{array}$} & \multirow[t]{2}{*}{$\%$} & \multirow[t]{2}{*}{$\mathbf{P}$} & \multirow[t]{2}{*}{ OR } \\
\hline & Baik & & Buruk & & & & & \\
\hline & $\mathbf{N}$ & $\%$ & $\mathbf{N}$ & $\%$ & & & & \\
\hline Baik & 22 & 95,7 & 1 & 4,3 & 23 & 100 & & 176,000 \\
\hline $\begin{array}{l}\text { Kurang } \\
\text { baik }\end{array}$ & 1 & 11,1 & 8 & 88,9 & 9 & 100 & 0,000 & \\
\hline Total & 25 & 100 & 7 & 100 & 32 & & & \\
\hline
\end{tabular}

Berdasarkan tabel 5 diatas menunjukan ada hubungan yang signifikan antara pengetahuanibu nifas tentang perawatan luka perineum dengan penyembuhan luka perineum. Dimana ibu yang berpengatahuan baik berpeluang 176 kali mengalami penyembuhan luka perineum dengan baik dibanding ibu nifas yang berpengetahuan kurang baik $(O R=176,000)$.

Tabel 7 Hubungan Sikap Ibu Nifas Tentang Perawatan Luka Perineum dengan Penyembuhan Luka Perineum

\begin{tabular}{|c|c|c|c|c|c|c|c|c|}
\hline \multirow[t]{2}{*}{$\begin{array}{c}\text { Sikap } \\
\text { Ibu }\end{array}$} & \multicolumn{4}{|c|}{$\begin{array}{l}\text { Penyembuhan } \\
\text { luka perineum }\end{array}$} & \multirow[t]{2}{*}{ Total } & \multirow[t]{2}{*}{$\%$} & \multirow[t]{2}{*}{$\mathbf{P}$} & \multirow[t]{2}{*}{ OR } \\
\hline & Baik & & Buruk & & & & & \\
\hline & $\mathbf{N}$ & $\%$ & & $\%$ & & & & \\
\hline \begin{tabular}{|l|l} 
Baik \\
\end{tabular} & 22 & 91,7 & 2 & 8,3 & 24 & 100 & & \\
\hline $\begin{array}{l}\text { Kurang } \\
\text { baik }\end{array}$ & 1 & 12,5 & 7 & 87,5 & 8 & 100 & 0,000 & 77,000 \\
\hline Total & 23 & 100 & 9 & 100 & 32 & & & \\
\hline
\end{tabular}

Berdasarkan tabel 6 diatas menunjukan bahwa ada hubungan yang signifikan antara sikap ibu nifas tentang perawatan luka perineum dengan penyembuhan luka perineum. Dimana ibu nifas yang bersikap baik berpeluang 77 kali mengalami penyembuhan luka perineum yang baik dibanding ibu yang bersikap kurang baik $(\mathrm{OR}=77,000)$.

\section{KESIMPULAN DAN SARAN}

Berdasarkan penelitian yang dilakukan dengan judul "Hubungan Pengetahuan dan Sikap Ibu Nifas Tentang Perawatan Luka Perineum dengan Penyembuhan Luka Perineum di Wilayah Kerja UPT. Puskesmas Gajah Mada dan Tembilahan Hulu Tahun 2019 " dengan jumlah responden 32 orang maka dapat disimpulkan bahwa :

a. Ada hubungan pengetahuan ibu nifas tentang perawatan luka perineum dengan penyembuhan luka perineum dengan nilai $p$ value 0,000 dengan nilai OR 176,000.

b. Ada hubungan sikap ibu nifas tentang perawatan luka perineum dengan 
penyembuhan luka perineum dengan nilai $p$ value 0,000 dengan nilai $O R$ 77,000 .

Saran bagi UPT Puskesmas Gajah Mada dan Puskesmas Tembilahan Hulu agar dapat meningkatkan pengetahuan ibu nifas dengan melakukan tindakan promotif seperti penyuluhanpada kunjungan pertama dengan menggunakan media yang bermuatan ilmu kesehatan dan pendidikan kesehatan atau Komunikasi Informasi Edukasi (KIE) kepada ibu tentang penerapan perawatan luka perineum dengan benar. Dengan demikian, diharapkan dapat mempermudah untuk proses penyembuhan luka perineum.

\section{DAFTAR PUSTAKA}

[1] Azwar, S (2013). Sikap Manusia: Teori dan Pengukurannya. Yogyakarta; Pusaka Pelajar

[2] Barbara, K (2012). Buku Ajar Keperawatan Fundamental Konsep Proses dan Praktik Edisi VII Volume I . Jakarta: EGC

[3] Dinas Kesehatan Provinsi Riau (2016). Profil Kesehatan Provinsi Riau Pekanbaru.

[4] Dinas Kesehatan Kabupaten Indragiri Hilir (2018). Profil Kesehatan Kabupaten Indragiri Hilir.

[5] Hidayat, AA (2014). Metode Penelitian Kebidanan dan Teknik Analisa Data. Jakarta; Salemba Medika

[6] Manuaba, I. B. G (2009). Memahami Kesehatan Reproduksi Wanita. Jakarta; EGC

[7] Martalina, D (2012). Asuhan Kebidanan Nifas dan Menyusui. Yogyakarta: Pustaka Belajar.

[8] Mubarak, W. I (2011). Promosi Kesehatan. Jogyakarta; Graha Ilmu.

[9] Maryam, S (2017) Promosi Kesehatan Dalam Pelayanan Kebidanan. Jakarta; EGC

[10] Moloku, W., Sambeka (2013). Hubungan Pengetahuan Tentang Perawatan dengan Penyembuhan Luka Episiotomi pada ibu post partum di Ruangan Irna D Bawah RSUP. Prof. Dr. R. D Kandow Melalayang. Manado. Diakses https://media.neliti.com/media/publicat ions/113475-ID-hubunganpengetahuan-tentang-perawatan-d.pdf

[11] Notoadmodjo, S (2010) Metode Penelitian Kesehatan. Jakarta; Rineka Cipta

[12] Nurrahmaton (2017). Hubungan Pengetahuan Ibu Nifas Tentang
Perawatan Luka Perineum Dengan Proses Penyembuhan Luka. Diakses di http://ejournal.helvetia.ac.id/index.php /jbk/article/view/3911.

[13] Rukiyah , A. Y., Yulianti, L (2018) Asuhan Kebidanan Nifas dan Menyusui. Jakarta; TIM.

[14] Smelzer, S dan Bare (2010). Buku Ajar Keperawatan Medikal Bedah. Jakarta; EGC

[15] Wawan, dkk (2010). Teori dan Pengukuran Pengetahuan Sikap dan Prilaku Manusia. Yogyakarta; Nuha Medika. 